\title{
Effect of water flow rate and feed training on "pacamã" (Siluriforme: Pseudopimelodidae) juvenile production
}

\author{
[Efeito do fluxo de água e do condicionamento alimentar na produção de juvenis de pacamã \\ (Siluriforme: Pseudopimelodidae)] \\ R.K. Luz $^{1}$, J.C.E. Santos ${ }^{2}$, M.M. Pedreira ${ }^{3}$, E.A. Teixeira ${ }^{1}$ \\ ${ }^{1}$ Escola de Veterinária - Universidade Federal de Minas Gerais - UFMG \\ Av. Antônio Carlos, 6627 \\ 31270-901 - Belo Horizonte, MG \\ ${ }^{2}$ Centro Integrado de Recursos Pesqueiros e Aquicultura de Três Marias - CODEVASF, MG \\ ${ }^{3}$ Universidade Federal dos Vales do Jequitinhonha e Mucuri - UFVJM, MG
}

\begin{abstract}
The effects of different water flow rates and feed training on the production of "pacamã" Lophiosilurus alexandri juveniles were evaluated. In the first experiment, nine day post-hatch larvae $(n=2,400)$ were stocked at a density of 5 larvae/L. Different water flow $(F)$ rates were tested: $F_{1}=180 ; F_{2}=600 ; F_{3}=$ 1,300 ; and $\mathrm{F}_{4}=2,600 \mathrm{~mL} / \mathrm{min}$. Artemia nauplii were offered as food during the first 15 days of active feeding. In the second experiment for feed training, 720 juveniles (total length of $22.2 \mathrm{~mm}$ ) were stocked at a density of 1.5 juveniles/L. A water flow rate similar to $F_{1}$ was used. The use of extruded dry diet was tested, and feed training was done with and without other enhanced flavors (Artemia nauplii or Scott emulsion). The water flow rates did not influence the survival or growth of $L$. alexandri. Cannibalism occurred during feed training. The worst survival, specific growth rate and high mortality were found with the use of extruded dry diet, while similar values were registered with the different feed training diets used. Reduced water flow rate can be used to lower water consumption during larviculture and feed training of L. alexandri.
\end{abstract}

Keywords: feed training, juvenile production, larviculture, Lophiosilurus alexandri, water flow

\section{RESUMO}

Avaliaram-se os efeitos de diferentes fluxos de água e do condicionamento alimentar sobre a produção de juvenis de pacamã Lophiosilurus alexandri. Larvas com nove dias pós-eclosão $(n=2.400)$ foram estocadas na densidade de 5 larvas/L. Diferentes fluxos $(F)$ de água foram testados: $F_{1}=180 ; F_{2}=600$; $F_{3}=1.300 ;$ e $F_{4}=2.600 \mathrm{~mL} / \mathrm{min}$. Náuplios de Artemia foram usados como alimento nos primeiros 15 dias de alimentação ativa. No segundo experimento, para o condicionamento alimentar, 720 juvenis (comprimento total de 22,2mm) foram estocados na densidade de 1,5 juvenis $/ \mathrm{L}$. Fluxo de água similar a $F_{1}$ foi utilizado. Foram testados o uso de dieta extrusada e o condicionamento alimentar adicionado ou não de náuplios de Artemia ou emulsão Scott. Os diferentes fluxos de água não afetaram a sobrevivência e o crescimento de $\mathrm{L}$. alexandri. Durante o condicionamento alimentar foi registrada a ocorrência de canibalismo. Pior sobrevivência, taxa de crescimento específica e maior mortalidade foram registradas para o uso da dieta comercial, enquanto valores similares foram verificados para as diferentes dietas usadas no condicionamento alimentar. Fluxo de água reduzido pode ser empregado durante a larvicultura e condicionamento alimentar de L. alexandri.

Palavras-chave: peixe, condicionamento alimentar, produção de juvenis, larvicultura, Lophiosilurus alexandri

Recebido em 24 de maio de 2010

Aceito em 23 de março de 2011

E-mail: luzrk@yahoo.com 


\section{INTRODUCTION}

The "pacamã" Lophiosilurus alexandri is a carnivorous freshwater fish, native to the São Francisco River, MG (Shibata, 2003) with the potential for farm production. Its meat is of excellent quality, taste and has few bones. This species is important for fisheries and in the reservoir restocking program, in which juveniles with a total length of over $1.5 \mathrm{~cm}$ are used.

High survival rates were recorded using Artemia nauplii as food during the first days of active feeding (Luz and Santos, 2008; Santos and Luz, 2009). However, the lack of research on the weaning strategies is one of the bottlenecks for the successful juvenile production of this species.

In the Integrated Center of Fisheries and Aquaculture Resources (ICFAR) of Três MariasCODEVASF, MG, the L. alexandri larviculture has been carried out with continuous water flow leading to high water consumption and waste. Davison (1997) related that for several salmonidae, the speed of water can increase the growth of animals and moderate their aggressive behavior. However, judicious use of water is necessary due to its importance to humans, animals and agriculture.

Weaning, which is generally done after some days or weeks after the beginning exogenous feeding, is considered a critical phase in the production of juveniles of carnivorous species. The difficulties are due to a high mortality rate that is attributed to the non-acceptance or difficulty to adapt to new diets (Duray and Bagarinao, 1984; Luz et al., 2002) and cannibalism (Qin et al., 1997; Luz, 2004; Ayres, 2006; Feiden et al., 2008). Among the weaning methods used, feed training consisting of the gradual transition of feed ingredients has been adopted for some carnivorous species (Kubtiza and Lovshin, 1997a, b; Moura et al., 2000; Luz et al., 2002: Luz, 2004; Soares et al., 2007; Feiden et al., 2008). However, weaning success depends on the species and the feeding management technique used.

The aim of this study was to evaluate the effect of different water flow rates and the feed training on the production of L. alexandri juveniles.

\section{MATERIALS AND METHODS}

The experiments were conducted at the Integrated Center of Fisheries and Aquaculture Resources of Três Marias-CODEVASF, MG. $L$. alexandri fertilized eggs were collected from two naturally spawn from brood stock adapted to captivity at CODEVASF. Eggs were incubated in a rectangular tank with a constant water flow.

For the experiment 1, 2,400 larvae of $L$. alexandri with nine days post-hatching (total length of $13.4 \pm 0.7 \mathrm{~mm}$ and wet weight of $22.4 \pm 1.3 \mathrm{mg}$ ) were stocked at a density of 5 larvae/L in 12 semicircular canals (120cm length) with 40-L of water, totally white, and under natural photoperiod (14L:10D). This batch of larvae was reared for the first 15 days of active feeding.

Different water flow rates $(\mathrm{F})$ were tested: $\mathrm{F}_{1}=$ $180 \pm 80 \mathrm{~mL} / \mathrm{min} ; \mathrm{F}_{2}=600 \pm 130 \mathrm{~mL} / \mathrm{min} ; \mathrm{F}_{3}=$ $1,300 \pm 300 \mathrm{~mL} / \mathrm{min}$; and $\mathrm{F}_{4}=2,600 \pm 500 \mathrm{~mL} / \mathrm{min}$, in triplicates. These water flow rates corresponded to approximately $0.3,1,2$, and 4 total renewals of the tank volume/h. In this system, rearing water was circulated once through the tank, without reuse. The $F_{4}$ is the water flow rate currently used in the ICFAR-Três Marias for L. alexandri rearing. The water flow rates were verified five times a day by measuring the water volume per 10 seconds.

For feeding, Artemia cysts were hatched daily in a $30 \%$ salt water. After 24 hours the hatching nauplii were concentrated in a $10 \%$ salt water for quantification and feeding. During the experiment the daily prey concentrations were 1,300 Artemia nauplii/larvae from first to fifth day of active feeding, 1,950 Artemia nauplii/larvae from sixth to tenth day of active feeding, and 2,600 Artemia nauplii/larvae from the eleventh to fifteenth day of active feeding. They were fed three times a day at $9 \mathrm{am}, 1 \mathrm{pm}$ and $5 \mathrm{pm}$. These prey concentrations were based on previous studies (data not published). For feeding the water flow was closed to avoid the loss of Artemia nauplii and then the nauplii were offered. After $30 \mathrm{~min}$, the water flows were adjusted according to the treatment.

Samples of 15 animals were taken from each canal after 15 days of feeding Measurements of total length $(\mathrm{mm})$ were recorded with an 
electronic caliper (Starret), and individual weights $(\mathrm{mg})$ for $0.0001 \mathrm{~g}$ precision were taken.

The temperature and dissolved oxygen were recorded daily at $12 \mathrm{am}$ (Oxymeter YSI 55). In the mornings, the canals were siphoned to remove the waste and dead larvae.

After the data analysis in the first experiment, 2,000 L. alexandri larvae with 9 days posthatching (total length of $13.1 \pm 0.5 \mathrm{~mm}$ and wet weight of $21.8 \pm 1.1 \mathrm{mg}$ ) of the second spawn were reared according to the feeding protocol described in Experiment 1, with a water flow rate of $200 \pm 50 \mathrm{~mL} / \mathrm{min}$. This water flow rate was chosen to reduce the water used during the rearing. The average water temperature was $25.5 \pm 1.8^{\circ} \mathrm{C}$ and the dissolved oxygen was higher than $4.5 \mathrm{mg} / \mathrm{L}$ at $12 \mathrm{am}$.

For experiment 2, after 15 days of active feeding (23 days post-hatching), 720 juveniles (total length of $22.2 \pm 1.4 \mathrm{~mm}$ and wet weight of $91.8 \pm 13.3 \mathrm{mg}$ ) were selected and stocked at a density of 1.5 juveniles/L in 12 canals (40-L each). The water flow rate of $200 \pm 50 \mathrm{~mL} / \mathrm{min}$ was maintained to reduce water waste. The mean temperature during the feed training was $25.0 \pm 0.8^{\circ} \mathrm{C}$ at $12 \mathrm{am}$.

Juveniles were directly fed with crumbled extruded dry diet (EDD) (diameter $<0.5 \mathrm{~mm}$ ) or feed training (FT) was based on the scheme used by Luz et al. (2002) (Table 1), up to the exclusive use of EDD. Additions of Artemia nauplii (FTA) or Scott emulsion (FTS) with cod liver oil enriched with vitamin $A$ and $D$ in the semi-moist diets were tested. The initial quantity of $10 \mathrm{~g}$ of Artemia nauplii was chosen to create a better mix of the initial semi-moist diet. This experiment was conducted in completely randomized design, and consisted of four treatments and three replicates.

In Table 2 the analysis of the diets and ingredient compositions used are shown, according to AOAC (Official..., 1984) methodology. To prepare the semi-moist diets, the ingredients were blended into a consistent and homogeneous mass. The diets were frozen after preparation and small portions were thawed for use during the day. For the FTA treatment the Artemia nauplii were concentrated and the excess moisture was eliminated using a dry paper before preparing the mix.

In this experiment, $98 \%$ of the canals' surfaces were covered with a black canvas in order to maintain the inside environment in almost complete darkness, and was uncovered only for daily feeding management and for cleaning. This management was based on previous methodology used for Hoplias lacerdae feed training (Luz et al., 2002). The juvenile were fed based on $120 \%$ of body weight. This quantity was divided into three equal amounts and fish were fed at $9 \mathrm{am}, 1 \mathrm{pm}$ and $5 \mathrm{pm}$. The canals were siphoned in order to remove the waste before feeding, and at this moment the cannibalism and mortality were quantified.

Table 1. Diets used during the feed training (FT) of Lophiosilurus alexandri juveniles ${ }^{1}$

\begin{tabular}{|c|c|c|c|}
\hline $\begin{array}{l}\text { Days of } \\
\text { feeding }\end{array}$ & Feed training $(\mathrm{FT})^{2}$ & $\begin{array}{c}\text { FT plus Artemia nauplii } \\
\text { (FTA) }\end{array}$ & $\begin{array}{c}\text { FT plus } \\
\text { Scott emulsion } \\
\text { (FTS) }\end{array}$ \\
\hline 1-3 days & $\begin{array}{c}80 \% \mathrm{OH}+20 \% \mathrm{EDD} \\
\text { (Diet } 1)\end{array}$ & $\begin{array}{c}\text { Diet } 1+10 \mathrm{~g} \text { Artemia } \\
\text { nauplii }\end{array}$ & $\begin{array}{c}\text { Diet } 1+10 \mathrm{~mL} \mathrm{Scott} \\
\text { emulsion }\end{array}$ \\
\hline 4-6 days & $\begin{array}{c}60 \% \mathrm{OH}+40 \% \mathrm{EDD} \\
(\text { Diet } 2)\end{array}$ & $\begin{array}{c}\text { Diet } 2+10 \mathrm{~g} \text { Artemia } \\
\text { nauplii }\end{array}$ & $\begin{array}{c}\text { Diet } 2+10 \mathrm{~mL} \mathrm{Scott} \\
\text { emulsion }\end{array}$ \\
\hline 7-9 days & $\begin{array}{c}40 \% \mathrm{OH}+60 \% \mathrm{EDD} \\
\text { (Diet 3) }\end{array}$ & $\begin{array}{c}\text { Diet } 3+5 \mathrm{~g} \text { Artemia } \\
\text { nauplii }\end{array}$ & $\begin{array}{c}\text { Diet } 3+5 \mathrm{~mL} \text { Scottt } \\
\text { emulsion }\end{array}$ \\
\hline 10-12 days & $20 \% \mathrm{OH}+80 \% \mathrm{EDD}$ & $20 \% \mathrm{OH}+80 \% \mathrm{EDD}$ & $20 \% \mathrm{OH}+80 \% \mathrm{EDD}$ \\
\hline 13-15 days & $\begin{array}{l}\text { Extruded dry diet } \\
\quad(100 \% \text { EDD })\end{array}$ & $\begin{array}{l}\text { Extruded dry diet } \\
\quad(100 \% \text { EDD })\end{array}$ & $\begin{array}{l}\text { Extruded dry diet } \\
\quad(100 \% \text { EDD })\end{array}$ \\
\hline
\end{tabular}

${ }^{1}$ The ingredient percentages of feed training diets are for the preparation of a mixture of $100 \mathrm{~g}$ of each diet.

${ }^{2}$ Methodology described by Luz et al. (2002).

$\mathrm{OH}$ - ox heart; EDD - extruded dry diet. 
Table 2. Ingredients and different diet composition (\% of dry matter basis) used during the feed training (experiment 2) of Lophiosilurus alexandri

\begin{tabular}{|c|c|c|c|c|c|c|c|c|c|c|c|c|c|}
\hline & 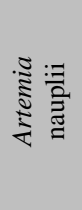 & 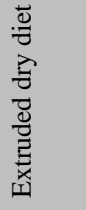 & 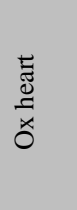 & $\stackrel{\Xi}{\stackrel{ \pm}{\theta}}$ & $\frac{N}{\stackrel{0}{0}}$ & $\stackrel{m}{\stackrel{\oplus}{0}}$ & $\stackrel{ナ}{\stackrel{ \pm}{\Delta}}$ & 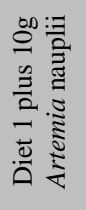 & 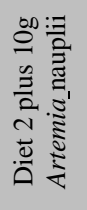 & 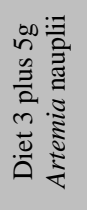 & 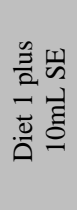 & 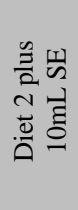 & 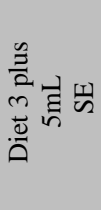 \\
\hline $\mathrm{CP}$ & 59.39 & 35.49 & 81.37 & 52.92 & 44.06 & 39.74 & 37.18 & 53.11 & 44.36 & 39.98 & 48.15 & 37.99 & 38.84 \\
\hline $\mathrm{CF}$ & 5.19 & 7.13 & 2.08 & 5.21 & 6.19 & 6.66 & 6.94 & 5.21 & 6.17 & 6.65 & 4,74 & 6.37 & 6.51 \\
\hline MM & 7.57 & 10.56 & 7.19 & 9.28 & 9.93 & 10.25 & 10.44 & 9.23 & 9.88 & 10.23 & 8.44 & 9.80 & 10.02 \\
\hline $\mathrm{Ca}$ & 0.19 & 1.81 & 0.19 & 1.19 & 1.51 & 1.66 & 1.75 & 1.16 & 1.48 & 1.65 & 1.09 & 1.59 & 1.62 \\
\hline $\mathrm{P}$ & 1.39 & 0.84 & 1.11 & 0.94 & 0.89 & 0.87 & 0.85 & 0.96 & 0.90 & 0.87 & 0.86 & 0.83 & 0.85 \\
\hline $\mathrm{EE}$ & 23.31 & 5.07 & 9.15 & 6.62 & 5.83 & 5.45 & 5.22 & 7.11 & 6.17 & 5.58 & 15.04 & 9.62 & 7.58 \\
\hline $\begin{array}{l}\mathrm{GE} \\
(\mathrm{k} / \mathrm{g})\end{array}$ & 17.94 & 17.82 & 21.14 & 19.08 & 18.44 & 18.13 & 17.95 & 19.05 & 18.43 & 18.13 & 20.00 & 18.62 & 18.38 \\
\hline
\end{tabular}

$\mathrm{CP}$ - crude protein; $\mathrm{CF}$ - crude fiber; $\mathrm{MM}$ - mineral matter; $\mathrm{Ca}$ - calcium; $\mathrm{P}$ - phosphorus; $\mathrm{EE}$ - ether extract; $\mathrm{GE}$ gross energy.

Diet $1(80 \% \mathrm{OH}+20 \% \mathrm{EDD})$; Diet $2(60 \% \mathrm{OH}+40 \% \mathrm{EDD})$; Diet $3(40 \% \mathrm{OH}+60 \% \mathrm{EDD})$; Diet $4(20 \% \mathrm{OH}+$ $80 \%$ EDD). OH - ox heart; EDD - extruded dry diet

SE - Scott emulsion composition (per 10mL): cod liver oil $(0.588 \mathrm{~g})$, soybean oil $(2.060 \mathrm{~g})$, monocalcium phosphate $(0.022 \mathrm{~g})$, dicalcium phosphate $(0.054 \mathrm{~g})$, sodium hypophosphite $(0.040 \mathrm{~g})$, essential oils $(0.014 \mathrm{~g})$, vehicle $(10 \mathrm{~mL})$, vitamin A (2,530UI) and vitamin D (253UI).

All juveniles were measured after 16 days of feed training (experiment 2) as described in experiment 1. For both experiments the specific growth rates (SGR) of fish were calculated according to the expression: $\mathrm{SGR}=\left(\left(\ln \mathrm{W}_{\mathrm{f}}-\ln \right.\right.$ $\left.\left.\mathrm{W}_{\mathrm{i}}\right) / \Delta \mathrm{t}\right) \times 100$, where $\mathrm{W}_{\mathrm{i}}$ and $\mathrm{W}_{\mathrm{f}}$ are the initial and final weights, respectively, and $\Delta \mathrm{t}$ is the time interval (in days).

At the end of the experiment 1, survival was estimated. At the end of the feed training (experiment 2), survival rates, mortality, and cannibalism (calculated by the number of individuals that had disappeared or were injured during the experiments) were estimated.

The percentage data was arcsin transformed but only the percentage results are presented. All data was analyzed using one-way ANOVA, and means were compared using Tukey's post-hoc test, at 5\% probability level. Statistical analysis were performed using the Statistica 7.0 program (Stat Soft, 2004).

\section{RESULTS}

In experiment 1 the $\mathrm{F}_{1}$ water flow rate had higher water temperature and lower dissolved oxygen level $(\mathrm{P}<0.05)$ (Table 3). Growth and survival were not significantly influenced $(\mathrm{P}>0.05)$ by different water flow rates. During this experiment no cannibalism was observed.

During the feed training (experiment 2), the darkness regimen kept the juveniles scattered in the canals, while in the natural photoperiod conditions of the initial phase, the larvae grouped together in the corners of the canals. During the daily management, when the tanks were uncovered, two different cannibalistic behaviors were observed: juveniles attacked others by the tails or attacked the heads of other juveniles. However, in both cases, juveniles did not swallow the prey (the other juvenile) because of the head shape of the animals. Soon captured preys were released during the management of feeding and cleaning, sometimes without a tail.

During the feed training period, the EDD showed lower growth, survival and mortality $(\mathrm{P}<0.05)$ (Table 4). Cannibalism was statistically similar between different treatments $(\mathrm{P}>0.05)$. There were no significant differences $(\mathrm{P}>0.05)$ in survival, mortality and specific growth rates among FT, FTA and FTS. The final weight was higher for FTA and FT. Higher values $(\mathrm{P}<0.05)$ of final length and biomass were registered when the juveniles were fed with FTA. 
Table 3. Means values ( \pm standard deviation) of water temperature, dissolved oxygen, growth and survival of Lophiosilurus alexandri in different water flow rates (experiment 1).

\begin{tabular}{lcccc} 
& $\mathrm{F}_{1}$ & $\mathrm{~F}_{2}$ & $\mathrm{~F}_{3}$ & $\mathrm{~F}_{4}$ \\
\hline Temperature $\left({ }^{\circ} \mathrm{C}\right)$ & $26.0 \pm 1.4 \mathrm{a}$ & $25.3 \pm 0.9 \mathrm{~b}$ & $25.0 \pm 0.7 \mathrm{~b}$ & $24.8 \pm 0.7 \mathrm{~b}$ \\
$\begin{array}{l}\text { Dissolved oxygen(mg/L) } \\
\text { Weight(mg) after 15 days }\end{array}$ & $4.1 \pm 0.7 \mathrm{~b}$ & $4.9 \pm 0.5 \mathrm{a}$ & $5.4 \pm 0.5 \mathrm{a}$ & $5.6 \pm 0.5 \mathrm{a}$ \\
$\begin{array}{l}\text { of active feeding } \\
\text { Length(mm) after 15 days }\end{array}$ & $24.6 \pm 0.4$ & $24.4 \pm 0.9$ & $132.9 \pm 21.8$ & $135.5 \pm 1.4$ \\
$\begin{array}{l}\text { of active feeding } \\
\text { SGR (\%/day) (1-15 days) }\end{array}$ & $12.8 \pm 0.7$ & $12.2 \pm 1.4$ & $23.7 \pm 0.6$ & $23.9 \pm 0.2$ \\
Survival(\%) & $74.5 \pm 7.9$ & $71.7 \pm 8.6$ & $11.7 \pm 1.1$ & $11.9 \pm 0.1$ \\
Seat & & $142.6 \pm 29.9$ & $74.9 \pm 4.2$ & $76.6 \pm 5.1$
\end{tabular}

Means followed by different letters within rows indicate significant differences through Tukey's test $(\mathrm{P}<0.05)$. $F$ - water flow rate: $F_{1}=180 \pm 80 \mathrm{~mL} / \mathrm{min} ; F_{2}=600 \pm 130 \mathrm{~mL} / \mathrm{min} ; F_{3}=1,300 \pm 300 \mathrm{~mL} / \mathrm{min} ;$ and $F_{4}=2,600 \pm 500 \mathrm{~mL} / \mathrm{min}$. $\mathrm{SGR}=$ specific growth rate.

Table 4. Means values ( \pm standard deviation) of survival, mortality, cannibalism, final length, final weight, final biomass and specific growth rate (SGR) of the Lophiosilurus alexandri juveniles after the feeding training period (experiment 2 ).

\begin{tabular}{lcccc}
\hline & Feed training $^{1}$ & FT plus Artemia & $\begin{array}{c}\text { FT plus Scott } \\
\text { emulsion }\end{array}$ & Extruded dry diet \\
\hline Survival(\%) & $61.6 \pm 10.9 \mathrm{a}$ & $73.8 \pm 1.9 \mathrm{a}$ & $60.5 \pm 0.9 \mathrm{a}$ & $26.6 \pm 5.0 \mathrm{~b}$ \\
Mortality(\%) & $32.7 \pm 8.2 \mathrm{a}$ & $21.6 \pm 6.6 \mathrm{a}$ & $35.5 \pm 3.4 \mathrm{a}$ & $65.0 \pm 13.6 \mathrm{~b}$ \\
Cannibalism(\%) & $5.5 \pm 5.8 \mathrm{a}$ & $4.4 \pm 5.1 \mathrm{a}$ & $3.8 \pm 3.8 \mathrm{a}$ & $8.3 \pm 8.8 \mathrm{a}$ \\
Final length(mm) & $26.5 \pm 0.5 \mathrm{ab}$ & $27.7 \pm 0.9 \mathrm{a}$ & $26.0 \pm 1.2 \mathrm{ab}$ & $24.2 \pm 0.9 \mathrm{~b}$ \\
Final weight(mg) & $196.3 \pm 3.1 \mathrm{a}$ & $224.3 \pm 28.3 \mathrm{a}$ & $188.6 \pm 17.9 \mathrm{ab}$ & $147.9 \pm 13.1 \mathrm{~b}$ \\
Final biomass(mg) & $7,207.6 \pm 1,210.6 \mathrm{~b}$ & $9,970.0 \pm 1,496.4 \mathrm{a}$ & $6,850.3 \pm 603.8 \mathrm{~b}$ & $2,350.0 \pm 340.4 \mathrm{c}$ \\
SGR(\%/day) & $5.1 \pm 0.1 \mathrm{a}$ & $5.9 \pm 0.8 \mathrm{a}$ & $4.7 \pm 0.6 \mathrm{a}$ & $3.1 \pm 0.6 \mathrm{~b}$ \\
\hline
\end{tabular}

Means followed by different letters within rows indicate significant differences through Tukey's test $(\mathrm{P}<0.05)$.

\section{DISCUSSION}

The lack of effects of water flow rates on the $L$. alexandri performance could be due to the grouping of animals at the bottom of the canals and showing activity only during feeding, when water flow was interrupted. This behavior is similar to that described by Travassos (1959), as this species is sedentary and prefers lentic environments. For juveniles of the California halibut Paralichthys californicus that also have a benthic behavior, different water flow did not affect survival; however, lower fluxes showed better growth (Merino et al., 2007).

On the other hand, in Arctic charr Salvelinus alpinus larviculture, an aggressive species that shows dominant hierarchy, water speed does affect larval growth (Grünbaum et al., 2008). These authors noted that the best growth was with the higher water flow rates tested, and attributed it to the reduction in aggressive behavior. For salmonidae, better growth is also associated with reduced agonistic behavior and with the enhanced food conversion efficiency and changes in aerobic metabolism due to the increase in water speed (Davison, 1997). However, the same author states that for nonsalmonidae, the results have varied according to the species. During L. alexandri larviculture, aggressive behavior was not observed at different water flow rates. It was observed that these animals showed little growth in total length and did not feed even with availability of food and consequently died.

When feed training began, cannibalism was observed even with excess food. This behavior was also observed with other species during the feed training (Kubitza and Lovshin, 1997a; Luz, 2004; Ayres, 2006; Feiden et al., 2008). Baras and Almeida (2001) stated that it is possible to classify cannibalism as type I - in which the prey is attacked by the tail and normally is bitten and released; and type II - in which the prey is attacked by the head. Both types of cannibalism were observed in the present study.

The use of dark conditions contributed to the low cannibalism rates observed in $L$. alexandri 
juveniles. The dark condition associated with adequate feed management enabled high survival rates in $\mathrm{H}$. lacerdae larviculture and feed training (Luz et al., 2002; Luz and Portella, 2002; Luz, 2004; Luz and Portella, 2005). However, during the feed training of Pseudoplatystoma corruscans, a Siluriform like $L$. alexandri, cannibalism rates above $40 \%$ were recorded (Ayres, 2006). This fact suggests that carnivorous fish of the same family can display different types of behavior.

After leaving the live food, the exclusive and continued use of a dry diet led to reduced growth and survival values during $L$. alexandri weaning. Similar results were verified for largemouth bass Micropterus salmoides (Kubitza and Lovshin, 1997b), H. lacerdae (Luz et al., 2002), and $P$. corruscans (Ayres, 2006). The high mortality observed in this study was also verified in $H$. lacerdae juveniles fed a dry diet and was directly evidenced by the non-acceptance of a diet without previous training (Luz et al., 2002), which was also confirmed for $P$. coruscans (Ayres, 2006). This fact also suggests that the dry diet offered immediately after leaving the live food did not present an adequately attractive appearance, texture and palatability to fish.

The feed training was a positive technique for acceptance of dry diets by $L$. alexandri juveniles. The survival rates, between 60 and $73 \%$ for the different treatments, were superior to $41.3 \%$ observed for $P$. corruscans, whose feed training program was also commenced with live Artemia nauplii for nine days (Ayres, 2006). Nevertheless, survival rates of $88 \%$ to $96.6 \%$ were recorded for H. lacerdae (Luz et al., 2002; Luz, 2004) using the same feed training methodology (FT), and 80 to $90 \%$ were recorded for M. salmoides (Feiden et al., 2008), using fish meal, tilapia fillet, ox heart or eviscerated sardine during the feed ingredients transition phase. The difference in results in the feed training of $L$. alexandri juveniles and of $H$. lacerdae (Luz et al., 2002; Luz, 2004), in which the same training methodology (FT) was adopted, could be attributed to the intrinsic behavior of each species or to factors related to the experimental conditions such as stocking density or initial size of animals.

The use of FTS with cod liver oil enriched with vitamins in the feed training did not yield good results compared to FT and FTA. With Cichla sp., the use of cod liver oil did not appear to be a flavor enhancer for this species either (Moura et al., 2000). Even though it is possible to use an FT diet, the resulting higher biomass indicates that the FTA diet is the most suitable for the feed training of $L$. alexandri juveniles. Kolkovski et al. (1997) stated that Artemia nauplii can be used with feed attractants and have an important role in the acceptance of dry diets by fish larvae due to the different substances (free amino acids) that are released by these prey. These same authors state that the Artemia nauplii can have strong effects on larval feeding activity and consumption as well as in enhancing growth.

\section{CONCLUSIONS}

Lophiosilurus alexandri larviculture and feed training can be done with a low water flow rate, reducing water use and waste. However, future studies should evaluate the growth of this species in different feeding farm conditions exclusively with dry diets.

\section{ACKNOWLEDGMENTS}

The authors thank CODEVASF/CEMIG, FAPEMIG, and CNPq for supporting this research. We would also like to thank Dr. Yoshimi Sato and Dr. Nilo Bazzoli for their assistance and support during this work.

\section{REFERENCES}

AYRES, T.J.S. Produção de juvenis de Pseudoplatystoma coruscans com dietas vivas $e$ formuladas. 2006. 60f. Dissertação (Mestrado em Aquacultura) - Centro de Aqüicultura da UNESP, Universidade Estadual Paulista, Jaboticabal, SP.

BARAS, E.; ALMEIDA, A.F. Size heterogeneity prevails over kinship in shaping cannibalism among larvae of sharptooth catfish Clarias gariepinus. Aquatic Liv. Res., v.14, p.251-256, 2001.

DAVISON, W. The effects of exercise training on teleost fish, a review of recent literature. Comp. Bioch. Physiol., v.117A, p. 67-75, 1997. 
DURAY, M.N.; BAGARINAO, T. Weaning of hatchery-bred milkfish larvae from live food to artificial diets. Aquaculture, v.41, p.325-332, 1984.

FEIDEN, A.; FERRARI , E.; BOSCOLO, W. R. et al. Desempenho e sobrevivência de alevinos de Black bass (Micropterus salmoides, Lacepède 1802), submetidos ao condicionamento alimentar, utilizando diferentes patês protéicos. Cienc. Agr., v.29, p.449-458, 2008.

GRÜNBAUM, T.; CLOUTIER, R.; FRANÇOIS, N. R. Le. Positive effects of exposure to increased water velocity on growth of newly hatched Arctic charr, Salvelinus alpines L. Aquacult. Res., v.39, p.106-110, 2008.

KOLKOVSKI, S.; KOVEN, W. M.; TANDLER. A. The mode of action of Artemia in enhancing utilization of microdiet by gilthead seabream Sparus aurata larvae. Aquaculture, v.155, p.193205, 1997.

KUBITZA, F.; LOVSHIN, L.L. Effects of initial weight and genetic strain on feed training largemouth bass Micropterus salmoides using ground fish flesh and freeze dried krill as starter diets. Aquaculture, v.148, p.179-190, 1997a.

KUBITZA, F.; LOVSHIN, L.L. The use of freeze-dried krill to feed train largemouth bass (Micropterus salmoides): feeds and training strategies. Aquaculture, v.148, p.299-312, 1997 b.

LUZ, R.K. Aspectos da larvicultura do trairão Hoplias lacerdae: manejo alimentar, densidade de estocagem e teste de exposição ao ar. 2004. 120f. Tese (Doutorado em Aquacultura) Centro de Aquicultura da UNESP, Universidade Estadual Paulista, Jaboticabal, SP. Disponível em: www.caunesp.unesp.br/Publicacoes/Dissertacoes _Teses/Teses/Tese\%20Ronald\%20Kennedy\%20 Luz.pdf. Acessado em: 22 jan. 2010.

LUZ, R.K.; PORTELLA, M.C. Diferentes densidades de estocagem na larvicultura do trairão Hoplias lacerdae. Acta Sci., v.27, p.95$101,2005$.

LUZ, R.K.; PORTELLA, M.C. Larvicultura de trairão (Hoplias lacerdae) em água doce e água salinizada. Rev. Bras. Zootec., v.31, p.829-834, 2002.
LUZ, R.K.; SALARO, A.L.; SOUTO, E.F. et al. Condicionamento alimentar de alevinos de trairão (Hoplias cf. lacerdae). Rev. Bras. Zootec., v.31, p.1881-1885, 2002.

LUZ, R.K.; SANTOS, J.C.E. Densidade de estocagem e salinidade da água na larvicultura do pacamã. Pesq. Agropec. Bras., v.43, p.903909, 2008.

MERINO, G.E.; PIEDRAHITA, R.H.; CONKLIN. D.E. Effect of water velocity on the growth of California halibut (Paralichthys californicus) juveniles. Aquaculture, v.271, p.206-215, 2007.

MOURA, M.A.M.; KUBITZA, F.; CYRINO, J.E.P. Feed training of peacock bass (Cichla sp.). Rev. Bras. Biol., v.60, p.645-654, 2000.

OFFICIAL methods of analysis. Arlington: AOAC, 1984. 1097p.

QIN, J.; FAST, A.W.; De ANDA, D. et al. Growth and survival of larval snakehead (Channa striatus) fed different diets. Aquaculture, v.148, p.105-113, 1997.

SANTOS, J.C.E.; LUZ, R.K. Effect of salinity and prey concentrations on Pseudoplatystoma corruscans, Prochilodus costatus and Lophiosilurus alexandri larviculture. Aquaculture, v.287, p.324-328, 2009.

SHIBATA, O.A. Family Pseudopimelodidae. In: REIS, R.E.; KULLANDER, S.O.; FERRARIS Jr., C.J. Check List of the Freshwater Fisher of South and Central America. Porto Alegre: EDIPUCRS, 2003. p.401-405.

SOARES, E.C.; PEREIRA-FILHO, M.; ROUBACH, R. et al. Condicionamento alimentar no desempenho zootécnico do tucunaré. Rev. Bras. Eng. Pesca, v.2, p.35-48, 2007.

STATSOFT INC. 2004. Statistica (data analysis software system). Version 7.

TRAVASSOS, H. Nótula sobre o pacamã, Lophiosilurus alexandri Steindachner, 1876. Atlas Soc. Biol., v.4, p.1-2, 1959. 